\title{
Bio efficacy of Heterorhabditis bacteriophora and Oscheius chongmingensis against Helopeltis theivora and Andraca bipunctata
}

\author{
Bharath Amuri ${ }^{*}$ and Gitanjali Devi \\ Department of Nematology, Assam Agricultural University, Jorhat, Assam, India \\ *Corresponding author
}

\begin{abstract}
A B S T R A C T
Native isolates of EPNs, Heterorhabditis bacteriophora and Oscheius chongmingensis were isolated from the tea plantation crop of Jorhat district of Assam and were tested against tea mosquito bug Helopeltis theivora andbunch caterpillar, Andraca bipunctata through mortality test under laboratory condition. For that 5, 10, 50, 100,150, 200 and 250 infective juveniles of each isolate were inoculated per insect. The insect mortality was observed after 24, 48, 72 and 96h exposure. It was observed that 50, 60 and 70 per cent mortality of $H$. theivora were recorded by $H$. bacteriophora (150 IJs/insect) at $48 \mathrm{~h}, 72 \mathrm{~h}$ and $96 \mathrm{~h}$ of exposure. It recorded that with the increase in the exposure period to $96 \mathrm{~h}, \mathrm{H}$. bacteriophora could induce up to $90 \%$ mortality of the tested insect at the dose of 250 IJs. Similarly, mortality of H.theivora increased with increase in the dosage of O.chongmingensis and recorded 50,60 and 70 per cent mortality at $200 \mathrm{IJs} / \mathrm{insect}$ at $48 \mathrm{~h}$, $72 \mathrm{~h}$ and $96 \mathrm{~h}$. Bioassay of $H$. bacteriophora and O. chongmingensis against the $3^{\text {rd }}$ instar larvae of A. Bipunctata indicated that at 250IJs/larva recorded 70 and $60 \%$ mortality in 48 hours of exposure, while 100 and $90 \%$ mortality of A. bipunctatawas recorded at 96h.However, in the present investigation, probit analysis revealed that $H$. bacteriophora showed maximum mortality than $O$. chongmingensis against $H$. theivora and $A$. bipunctata at $48 \mathrm{~h}, 72 \mathrm{~h}$ and $96 \mathrm{~h}$ of exposure time.
\end{abstract}

\section{Introduction}

Tea (Camellia sinensis L.) belonging to the family Theaceae and tribe Gordonaceae is a long duration perennial crop grown under monoculture. Tea leaves are mostly plucked for the making of tea beverages like green tea and black tea and it contain the polyphenols such as catechins and epicatechins. Such compounds act as antioxidant and provide health benefits like reduction of weight loss, the risk of diabetes and cardiovascular disease.

The crop is extensively cultivated in 13 states of India out of which Assam, West Bengal, Tamil Nadu and Kerala are the largest producers. In Assam, it is cultivated on 765 tea gardens covering an area of 307.08 thousands hectares and more than $17 \%$ 
workers of Assam are engaged in the tea industry (Anonymous, 2018).The total annual production of tea in Assam is 676.31 million $\mathrm{kg}$ in year 2017-18, which is more than 50 percent of India's total tea production (Anonymous, 2018). Crop loss in tea due to pests, diseases and weeds varies between 715\% (Borthakur et al., 1992). Pest infestation is a major problem associated with tea cultivation that caused reduction not only in the quantity but also in quality of tea. Tea plantation provides a permanent ecosystem for more than1034 arthropods (Chen and Chen, 1989). Das (1965) reported that 167 species of arthropods have been noted from the northeast India and cause 11.00-55.00\% annual yield loss. Among them, tea mosquito bug, Helopeltis theivora (Waterhouse) (Hemiptera: Miridae) is one of them. H.theivora becomes the greatest enemies of tea planters in Africa and Asia causing 55\% and $11-100 \%$ crop loss, respectively (Wilson and Clifford 1992; Anonymous, 1994; Sundararaju and Sundara Babu, 1999). In Assam $H$. theivora caused 15-20\% crop loss (Hazarika et al., 2009; Anonymous, 2010). This particular pest causes damage to tea plant throughout the year but the incidence is more severe during the months of MaySeptember.

Bunch caterpillars, Andraca bipunctata Walk. (Lepidoptera: Bombycidae) is a well-known pest of tea (Watt and Mann, 1903) and mostly occurs in India, Indonesia, Taiwan, China, and Vietnam. In India, the pest is reported from Assam, Sikkim, and West Bengal. The hatched larvae feed on the shoot, bud, young leaves, and matured leaves in a group and completely defoliate the tea plant causing 15\% yield loss in Assam (Anonymous, 2010).

Nematodes which are capable of killing, sterilizing or hampering the development of insect and completing at least one stage of their life cycle in the host are called entomopathogenic nematodes (EPNs). Entomopathogenic nematodes, Steinernema and Heterorhaditis in the family Steinernematidae and Heterorhabditidae of the order Rhabditida are obligate parasites of insect pests. The other genus Oscheius, in the family Rhabditidae, is also recently been isolated and found to be entomopathogenic.

EPNs are considered as one of the most significant non-chemical alternatives to insect pest control due to their high reproductive potential, ease of mass production and their harmlessness to microbes, animals, humans and plants. Only the third juvenile stage is the infective juvenile that is free-living in the soil, non-feeding, encased in a double cuticle with closed mouth and anus and capable of surviving for several weeks in the soil, before infecting a new host individual.

The infective juveniles actively penetrate through the mid gut wall or tracheae into the insect body cavity (hemocoel) containing insect haemolymph. EPNs have a mutualistic partnership with gram-negative gammaproteobacteria in the family Enterobacteriaceae. Xenorhabdus bacteria are associated with steinernematid nematodes while Photorhabdus are symbionts of heterorhabditids.

Photorhabdus and Xenorhabdus, are carrying in their intestines, whereas Heterorhabditidoides (=Oscheius) carry symbiotic bacterial strains of Serratia in both the intestine and the cuticle (Kaya and Gaugler, 1993; Torres-Barragan et al., 2011; Zhang et al., 2008, 2009, 2012).

Nematode and bacteria overcome the insect immune system and the host insect is killed within 24-48 hours post infection (Adams and Nguyen, 2002). The EPNs thrives in wide range of climatic conditions and distributed in natural and agricultural soils. They have 
enormous potential as biocontrol agent against a wide range of insect pests but their pathogencity varied from species to species and /or strain to strain. The application of native isolates found to be a prime importance for the management of insect pest of various crops because they share common niche with their host. The present study was undertaken to evaluate the best native isolates of EPN against tea pestlike $H$. theivora and A.bipunctata under in-vitro condition through bio efficacy test.

\section{Materials and Methods}

\section{Collection and preparation of insects}

Helopeltis theivora and Andraca bipunctata were collected from the sites in tea (Camellia sinensis) plantation areas (26.714910"N 94.204440"E) of AAU, Jorhat, Assam, India. The collected insects used in the experiment were kept in large plastic containers in laboratory at room temperature $\left(25-30^{\circ} \mathrm{C}\right)$. The adults of $H$. theivora, having the average weight of $6.48 \pm 0.13 \mathrm{mg}$ and $3^{\text {rd }}$ stage larvae of A. bipunctata average weight of $519.70 \pm 2.70 \mathrm{mg}$ were separated and used for infectivity test.

\section{Maintenance of nematode culture}

The entomopathogenic nematodes viz., Heterorhabditis bacteriophora and Oscheius chongmingensis were isolated from tea through Galleria bating technique and were continuously multiply on larva of greater wax moth, G. mellonella. The insect larvae were exposed to the nematode as per the method described by Woodring and Kaya (1988).

About ten larvae of $G$. mellonella were released into a Petri dish over two Whatman No.1 filter papers inoculated with infective juveniles stored in sterile distilled water $(1 \mathrm{ml}$ suspension containing 200 infective juveniles). The Petri dishes were sealed with cling film and stored in polythene bags to conserve moisture. The infective juveniles of nematodes were harvested by using White Traps as described by White (1927). The nematode multiplications in $G$. mellonella were continued in batches and the infective juveniles (IJs) were collected up to 12 days of inoculation. These juveniles were washed and rinsed several times with sterile distilled water. The collected IJs were preserved in a beaker at $10^{\circ} \mathrm{C}$ and utilized within two days for the study.

\section{Infectivity assay}

The infectivity tests were carried out in cavity block $(55 \mathrm{~mm} \times 55 \mathrm{~mm})$ lined with a wet filter paper. One larva/adult of test insect was placed in each cavity block. Infective juveniles of $H$. bacteriophora and $O$. chongmingensis were inoculated at 0 (control), 10, 50, 100,150, 200 and 250 /insect. In control the insects were not exposed to the nematodes. The cavity blocks were wrapped with tiny perforated polyethylene bag and kept at room temperature in a dark room $\left(30 \pm 2^{\circ} \mathrm{C}\right)$ and replicated 10 times along with control.

Insect mortality was observed after 24, 48, 72 and $96 \mathrm{~h}$ exposure. Dead insects were dissected and the hemolymph of each one was observed under a stereoscopic microscope. When nematodes in different stages of development were detected, we considered they were the cause of death.

The mortality data (expressed in percentage) were transformed to arc sine and subjected to analysis of variance. The means were separated by Duncan's Multiple Range Test (SPSS, 2007). The corrected per cent mortality was computed after considering kill in control treatment. The $\mathrm{LD}_{50}$ was calculated using probit analysis and all comparisons 
were made at $P=0.05$ level of significance (Hewlett and Placket, 1979).

\section{Results and Discussion}

In infectivity study, indigenous isolates of EPNs, viz., $H$. bacteriophora and $O$. chongmingensis tested in the laboratory bioassay caused mortality of $H$. theivora and A. bipunctata (Table 1). The data revealed that $H$. theivora exposed to $H$. bacteriophora and $O$. chongmingensis exhibited increase in mortality with increase in exposure time coupled with inoculation rate.

No insect mortality was recorded at $24 \mathrm{~h}$ exposure with these nematodes. Fifty, 60 and 70 per cent mortality of $H$. theivora at 150 $\mathrm{IJ}$ /insect was observed at $48 \mathrm{~h}, 72 \mathrm{~h}$ and $96 \mathrm{~h}$ respectively. With the increase in the exposure period to $96 \mathrm{~h}, H$. bacteriophora could induce up to $90 \%$ mortality of the tested insect at the dose of 250 IJs. Similarly, mortality of $H$. theivora increased with increase in the dosage of $O$. chongmingensis and recorded 50, 60 and 70 per cent mortality at $200 \mathrm{IJ}$ s/insect at $48 \mathrm{~h}, 72 \mathrm{~h}$ and 96h.However, there was no significant difference between the dose of IJs, i.e., 150, 200 and 250 for mortality of $H$. theivora adult when they were treated with $H$. bacteriophora and O.chongmingensis. Bioassay of $H$. bacteriophora and $O$. chongmingensis against the 3rd instar larvae of A. Bipunctata indicated that at 250IJs/larva recorded 70 and $60 \%$ mortality in 48 hours of exposure, while 100 and $90 \%$ mortality of A. bipunctata was recorded at $96 \mathrm{~h}$, respectively (Table 2). However, there was no significant difference in the dose of IJs, i.e., 100,150,200,250 for mortality of $A$. bipunctata larvae when they were treated with $H$. bacteriophora. Similarly, no significant difference was found in the dose of IJs, i.e. 150,200,250/larvae for mortality of $A$. bipunctata when they were treated with $O$. chongmingensis.
The $\mathrm{LD}_{50}$ values determined from different dosage levels for both EPN species against $H$. theivora and $A$. bipunctata indicated that $H$. bacteriophora was superior to O.chongmingensis with the lowest $\mathrm{LD}_{50}$ at 48 $\mathrm{h}, 72 \mathrm{~h}$ and $96 \mathrm{~h}$ exposure (Table 3). The $\mathrm{LD}_{50}$ values for $H$. bacteriophora were $150.61(95 \%$ FL 76.58-221.58), 101.92 (95\% FL 44.23144.44) and 38.23 (95\% FL 9.63-101.28) at 48, 72 and $96 \mathrm{~h}$ of exposures on $H$. theivora. The $\mathrm{LD}_{50}$ values decreased when exposure period was increased (Table 4).

The $\mathrm{LD}_{50}$ values for O.chongmingensis were 205.31 (95\% FL 98.67-458.90), 150.92 (95\% FL 84.43-241.23) and 87.02 (95\% FL 48.61155.77) at 48, 72 and $96 \mathrm{~h}$ of exposure on $H$. theivora. The $\mathrm{LD}_{50}$ values for $H$. bacteriophora were 150.61 (95\% FL 76.58221.58), 95.65 (95\% FL 51.97-176.04) and 45.49 (95\% FL 19.48-105.68) at 48, 72 and $96 \mathrm{~h}$ of exposures on larvae of $A$. bipunctata, respectively. The $\mathrm{LD}_{50}$ values for $O$. chongmingensis were 201.65 (95\% FL 82.82248.75), 133.87 (95\% FL 66.76-248.65) and 77.96 (95\% FL 31.13-195.23) at 48, 72 and $96 \mathrm{~h}$ of exposures on A.bipunctata. Thus, the present study confirmed the biocontrol potential of indigenous entomopathogenic nematodes $H$. bacteriophora and $O$. chongmingensis against $H$. theivora and $A$. bipunctata.

Pathogenicity of two indigenous species of entomopathogenic nematodes (EPNs), viz., $H$. bacteriophora and $O$. chongmingensis to $H$. theivora and $A$. bipunctata was studied under laboratory conditions with bioassay techniques.

Mortality of $H$. theivora and $A$. bipunctata increased with increase in dosage. The adult mortality of $H$. theivora was $90 \%$ and $80 \%$ per cent in $96 \mathrm{~h}$ exposure period at the dose of 250 infective juveniles (IJs) of $H$. bacteriophora and $O$. chongmingensis, respectively. 
It was least at $5 \mathrm{IJ}$ s/adult. Similarly, the larval mortality of $A$. bipunctata was $100 \%$ and $90 \%$ per cent in $96 \mathrm{~h}$ exposure period at the dose of 250 infective juveniles (IJs) of $H$. bacteriophora and $O$. chongmingensis, respectively. It was least at $10 \mathrm{IJ} /$ /larva of all EPNs tested. Of the two isolates tested, $H$. bacteriophora were more effective against both of the insect thanO. chongmingensis. The present record on $\mathrm{LC}_{50}$ of both the EPNs indicated that $H$. bacteriophora required less number of IJs $(150.61,101.92,38.23)$ than $O$. chongmingensis $(205.31,150.92,87.02)$ toresult $50 \%$ mortality of adult of $H$. theivora at $48 \mathrm{~h}, 72 \mathrm{~h}$ and $96 \mathrm{~h}$ indicating higher pathogenicity of $H$. bacteriophora compared to $O$. chongmingensis. Similarly, $\mathrm{LC}_{50}$ of both the EPNs recorded that $H$. bacteriophora required a smaller number of IJs $(150.61,95.65,45.49)$ than $O$. chongmingensis $(201.65,133.87,77.96)$ toresult $50 \%$ mortality of larvae of $A$. bipunctata at $48 \mathrm{~h}, 72 \mathrm{~h}$ and 96h.

During present study, with different dose of IJs of H.bacteriophora and $O$. chongmingensis, $H$. theivora and A.bipunctata are recorded as good host. However, there was no significant difference between the dose of IJs, i.e., 100, 150, 200 and 250 for mortality of $H$. theivora adult and A. bipunctata larvae when they were treated with $H$. bacteriophora and $O$. chongmingensis, respectively. A similar result was reported by Leite et al., (2007) according to whom $H$. indica (IBCB-n05), applied in concentrations of 5.7 and $22.6 \mathrm{IJ} / \mathrm{cm}^{2}$, the concentrations did not influence the virulence of the tested EPN strains as did not present any statistical difference, reaching efficiency of $75 \%$ and $85 \%$, respectively, to control Bradysia mabiusi larvae and by Batista et al., (2011) who applied three different concentrations of EPNs on M. fimbriolata in Petri dishes and noticed that this did not influence nymph mortality.
Vyas and Yadav (1992) found ina laboratory bioassay of $S$. glaseri against Agrotisipsilon and $S$. litura, cent per cent larval mortality at 16 and $32 \mathrm{IJs} / \mathrm{g}$ of soil after $72 \mathrm{~h}$ of exposure period respectively. Gupta et al., (1987) reported 66 per cent cutworm, S. litura mortality in tobacco. Baweja and Sehgal (1997) also observed 80 per cent mortality of $S$. Litura due to $H$. bacteriophora. Similar results were also reported by Kondo and Ishibashi (1986) and, Ricci et al., (1995) in $S$. litura. Rajkumar et al., (2003) The $\mathrm{LD}_{50}$ values for prepupa of $S$. litura at different exposure periods (12, 24, 36 and 48 hours) were 55.73, 33.44, 16.68and 10.49 (IJs/larva). Hussaini et al., (2002) obtained centpercent mortality of $L$. orbonalis with $S$. carpocapsae with 25 IJs / larva but only after 96 hrs.

Stokwe and Malan, (2010) in a laboratory bioassay showed that both adult and intermediate life stages of Pseudococcus viburni (Signoret) were most susceptible to $H$. zealandica and S. yirgalemense with $78 \%$ and $76 \%$ mortality respectively. $P$. citri, the citrus mealy bug was susceptible to $H$. zealandica (with 91\% mortality) and S. yirgalemense (with 97\% mortality). Both species were able to complete their life cycles within the insect host, while $S$. yirgalemense proved to be faster at locating and infecting $P$. citrithan $H$. zealandica (Van Niekerk, 2012). Bioassays were done on Petri dishes infested with females of $P$. citri, which were sprayed with juveniles of 18 numbers of different EPN strains. The strain with larger pathogenicity and virulence in laboratory was $H$. bacteriophora $\mathrm{RS} 33$ (from $69.0 \%$ to $92.2 \%$ of mortality) (Negrisoli et al., 2013).

In a laboratory bioassay test conducted by Zaki et al., 2000, recorded that $H$ bacteriophora caused 5, 40, 80, and 100\% mortality of Corcyra cephalonica within 24, 48, 72 and 96 hours at 15 IJs per larva . 
Similarly, S. carpocapsae resulted in 40,75 and $100 \%$ mortality of C. cephalonica after 48, 72 and 96 hours of application at same inoculums level. $H$. bacteriophora and $S$. carpocapsae caused 40 and $48 \%$ mortality of Bombyx mori after $48 \mathrm{~h}$. Cent per cent mortality of $4^{\text {th }}$ instar larva of A. ipsilon was brought about by H.bacteriophora and $S$. carpocapsae at the rate of 25 IJs within 77 and 96 hours respectively.

Efficacy of Oscheius sp. against spindle bug and red ant in areca nut (Mohandas and Rajamma, 2005; Mohandas et al., 2005), rice yellow stem borer (Gururaj Katti et al., 2003; Prasad et al., 2003; Padmakumari et al., 2005; Pudmakumari et al., 2007) have been documented in India.Ratnasinghe and Hague
(1995) have reported $\mathrm{LD}_{50}$ value of 3.6 IJ/larva of S. feltiae against Plutellaxylostella. Glazer and Navon (1990) recorded a higher $\mathrm{LD}_{50}$ value of $54 \mathrm{IJ} /$ larva of $S$. feltiae against Helicoverpaarmigera, however, a lower $\mathrm{LD}_{50}$ value of $10.51 \mathrm{IJ} /$ larva and $\mathrm{LT}_{50}$ value of $47.54 \mathrm{~h}$ were reported for $S$. glaseri against $H$. armigera.

Saravanapriya (2005) also reported lower $\mathrm{LC}_{50}$ values of 9.4, 7.3, 5.5 and $2.0 \mathrm{IJ} / /$ arva of $H$. indica compared to those of $S$. carpocapsae with $10.5,9.0,5.2$ and 2.5 IJs/larva against fifth instar larvae of Heliothis armigera., S. litura, Cnaphalocrocis medinalis and P. xylostella, respectively (Fig. $1-7)$.

Table.1 Per cent mortality of $H$. theivora induced by $H$. bacteriophora and $O$. chongmingensis at different dose and different time exposure

\begin{tabular}{|c|c|c|c|c|c|}
\hline \multirow[t]{2}{*}{ Nematode } & \multirow[t]{2}{*}{ Dose/insect } & \multicolumn{4}{|c|}{ Mortality (\%) after } \\
\hline & & $24 \mathrm{~h}$ & $48 h$ & $72 \mathrm{~h}$ & $96 \mathrm{~h}$ \\
\hline \multirow{7}{*}{$\begin{array}{l}\text { Heterorhabditis } \\
\text { bacteriophora }\end{array}$} & 5 & 0 & $10(09.18)$ & $20(18.14)$ & $30(27.09)$ \\
\hline & 10 & 0 & $20(18.14)$ & $30(27.09)$ & $40(36.04)$ \\
\hline & 50 & 0 & $30(27.09)$ & $40(36.04)$ & $50(45.00)$ \\
\hline & 100 & 0 & $40(36.04)$ & $50(45.00)$ & $60(53.95)$ \\
\hline & 150 & 0 & $50(45.00)$ & $60(53.95)$ & $70(62.90)$ \\
\hline & 200 & 0 & $60(53.95)$ & $70(62.90)$ & $80(71.86)$ \\
\hline & 250 & 0 & $70(62.90)$ & $80(71.86)$ & $90(80.81)$ \\
\hline \multirow{7}{*}{$\begin{array}{l}\text { Oscheius } \\
\text { chongmingensis }\end{array}$} & 5 & 0 & $0(0.23)$ & $10(9.18)$ & $30(27.09)$ \\
\hline & 10 & 0 & $10(9.18)$ & $20(18.14)$ & $40(36.04)$ \\
\hline & 50 & 0 & $20(18.14)$ & $30(27.09)$ & $40(36.04)$ \\
\hline & 100 & 0 & $30(27.09)$ & $40(36.04)$ & $50(45.00)$ \\
\hline & 150 & 0 & $40(36.04)$ & $50(45.00)$ & $60(53.95)$ \\
\hline & 200 & 0 & $50(45.00)$ & $60(53.95)$ & $70(62.90)$ \\
\hline & 250 & 0 & $60(53.95)$ & $70(62.90)$ & $80(71.86)$ \\
\hline Control & & 0 & $0(0.23)$ & $10(9.18)$ & $20(18.14)$ \\
\hline Mean & & 0 & $32.66(29.47)$ & $42.66(38.43)$ & $54.00(48.57)$ \\
\hline $\mathrm{CD}(0.05)$ & & & (34.37) & (36.74) & (37.66) \\
\hline
\end{tabular}

Mean of ten replicates with one insect per replication. Figures in parentheses are arc sin transformed values 
Table.2 Per cent mortality of $A$. bipunctata induced by $H$. bacteriophora and $O$. chongmingensis at different dose and different time exposure

\begin{tabular}{|c|c|c|c|c|c|}
\hline \multirow{2}{*}{ Nematode } & \multirow[t]{2}{*}{ dose/insect } & \multicolumn{4}{|c|}{ Mortality (\%) after } \\
\hline & & $24 \mathrm{~h}$ & $48 \mathrm{~h}$ & $72 \mathrm{~h}$ & $96 \mathrm{~h}$ \\
\hline \multirow{7}{*}{$\begin{array}{l}\text { Heterorhabditis } \\
\text { bacteriophora }\end{array}$} & 5 & 0 & $10(9.18)$ & $20(18.14)$ & $40(36.04)$ \\
\hline & 10 & 0 & $20(18.14)$ & $30(27.09)$ & $50(45.00)$ \\
\hline & 50 & 0 & $30(27.09)$ & $40(36.04)$ & $60(53.95)$ \\
\hline & 100 & 0 & $40(36.04)$ & $50(45.00)$ & $70(62.90)$ \\
\hline & 150 & 0 & $50(45.00)$ & $60(53.95)$ & $80(71.86)$ \\
\hline & 200 & 0 & $60(53.95)$ & $70(62.90)$ & $90(80.81)$ \\
\hline & 250 & 0 & $70(62.90)$ & $80(71.86)$ & $100(89.76)$ \\
\hline \multirow{7}{*}{$\begin{array}{l}\text { Oscheius } \\
\text { chongmingensis }\end{array}$} & 5 & 0 & $0(0.23)$ & $10(9.18)$ & $30(27.09)$ \\
\hline & 10 & 0 & $10(9.18)$ & $20(18.14)$ & $40(36.04)$ \\
\hline & 50 & 0 & $20(18.14)$ & $30(27.09)$ & $50(45.00)$ \\
\hline & 100 & 0 & $30(27.09)$ & $40(36.04)$ & $60(53.95)$ \\
\hline & 150 & 0 & $40(36.04)$ & $60(53.95)$ & $70(62.90)$ \\
\hline & 200 & 0 & $50(45.00)$ & $70(62.90)$ & $80(71.86)$ \\
\hline & 250 & 0 & $60(53.95)$ & $80(71.86)$ & $90(80.81)$ \\
\hline Control & & 0 & $0(0.23)$ & $0(0.23)$ & $10(9.18)$ \\
\hline Mean & & 0 & $32.66(29.47)$ & $44.00(39.62)$ & $61.33(55.14)$ \\
\hline $\mathrm{CD}(0.05)$ & & & $(34.37)$ & (35.61) & (34.96) \\
\hline
\end{tabular}

Mean of ten replicates with one insect per replication. Figures in parentheses are arc sin transformed values

Table.3 Dose response mortality of $H$. theivora by $H$. bacteriophora and $O$. chongmingensis

\begin{tabular}{|c|c|c|c|c|c|c|}
\hline Exposure time & $\mathbf{L D}_{50}$ & $\begin{array}{l}\text { Fiducial limits } \\
(95 \%)\end{array}$ & Slope & $\chi^{2}$ & $\begin{array}{l}\text { Regression equation } \\
\text { (Y) }\end{array}$ & $\mathbf{R}^{2}$ \\
\hline \multicolumn{7}{|c|}{ H. bacteriophora } \\
\hline $48 h$ & 150.61 & $76.58-221.58$ & 0.93 & 0.85 & $0.93 x+3.05$ & 1 \\
\hline $72 \mathrm{~h}$ & 101.92 & $44.23-144.44$ & 0.98 & 1.29 & $0.98 x+3.39$ & 1 \\
\hline $96 \mathrm{~h}$ & 38.23 & $9.63-101.28$ & 1.09 & 2.67 & $1.09 x+3.36$ & 1 \\
\hline \multicolumn{7}{|c|}{ O. chongmingensis } \\
\hline $48 h$ & 205.31 & $98.67-458.90$ & 1.09 & 0.65 & $1.09 x+2.44$ & 1 \\
\hline $72 \mathrm{~h}$ & 150.92 & $84.43-241.23$ & 1.84 & 1.69 & $1.84 x+0.97$ & 1 \\
\hline $96 \mathrm{~h}$ & 87.02 & $48.61-155.77$ & 1.39 & 1.67 & $1.39 x+2.29$ & 1 \\
\hline
\end{tabular}


Table.4 Dose response mortality of $A$. bipunctata by $H$. bacteriophora and $O$. Chongmingensis

\begin{tabular}{|c|c|c|c|c|c|c|}
\hline Exposure time & $\mathbf{L D}_{50}$ & $\begin{array}{c}\text { Fiducial limits } \\
\qquad(95 \%)\end{array}$ & Slope & $\chi^{2}$ & $\begin{array}{c}\text { Regression equation } \\
\text { (Y) }\end{array}$ & $\mathbf{R}^{2}$ \\
\hline \multicolumn{7}{|c|}{ H. bacteriophora } \\
\hline $48 h$ & 150.61 & $76.58-221.58$ & 0.93 & 0.85 & $0.93 x+3.05$ & 1 \\
\hline $72 \mathrm{~h}$ & 95.65 & $51.97-176.04$ & 1.31 & 0.46 & $1.31 x+2.39$ & 1 \\
\hline $96 h$ & 45.49 & $19.48-105.68$ & 1.08 & 2.06 & $1.08 x+3.16$ & 1 \\
\hline \multicolumn{7}{|c|}{ O. chongmingensis } \\
\hline $48 h$ & 201.65 & $82.82-248.75$ & 1.10 & 0.60 & $1.10 x+2.44$ & 1 \\
\hline $72 \mathrm{~h}$ & 133.87 & $66.76-248.65$ & 1.19 & 0.45 & $1.19 x+2.45$ & 1 \\
\hline $96 h$ & 77.96 & $31.13-195.23$ & 0.90 & 1.18 & $0.90 x+3.28$ & 1 \\
\hline
\end{tabular}

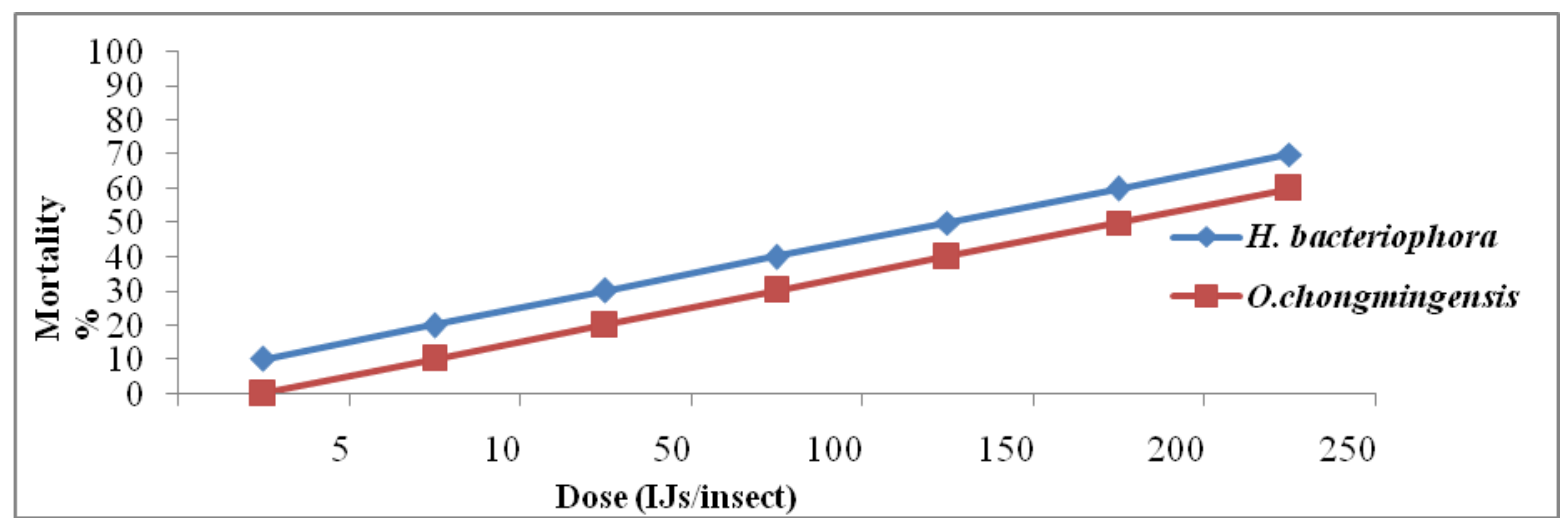

Figure.1 Per cent mortality of $H$. theivora induced by $H$. bacteriophora and $O$. chongmingensis at different concentrations of EPNs at $48 \mathrm{~h}$ exposure period

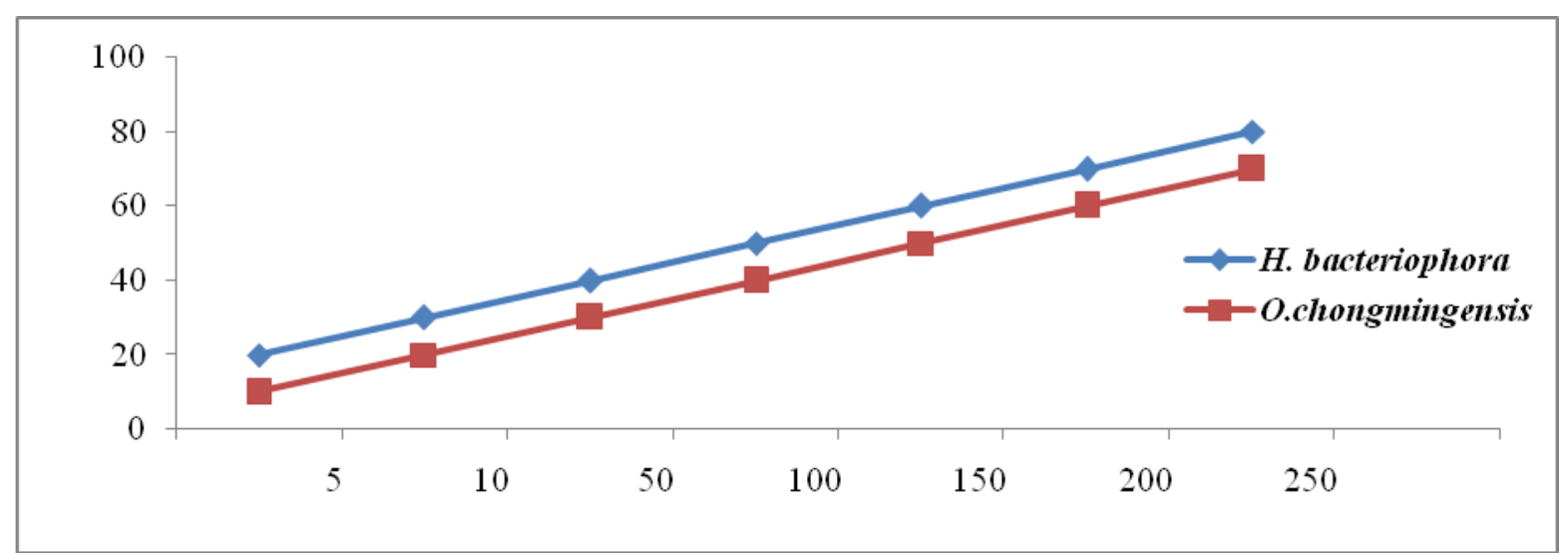

Figure.2 Per cent mortality of $H$. theivora induced by $H$. bacteriophora and $O$. chongmingensis at different concentrations of EPNs at $72 \mathrm{~h}$ exposure period 


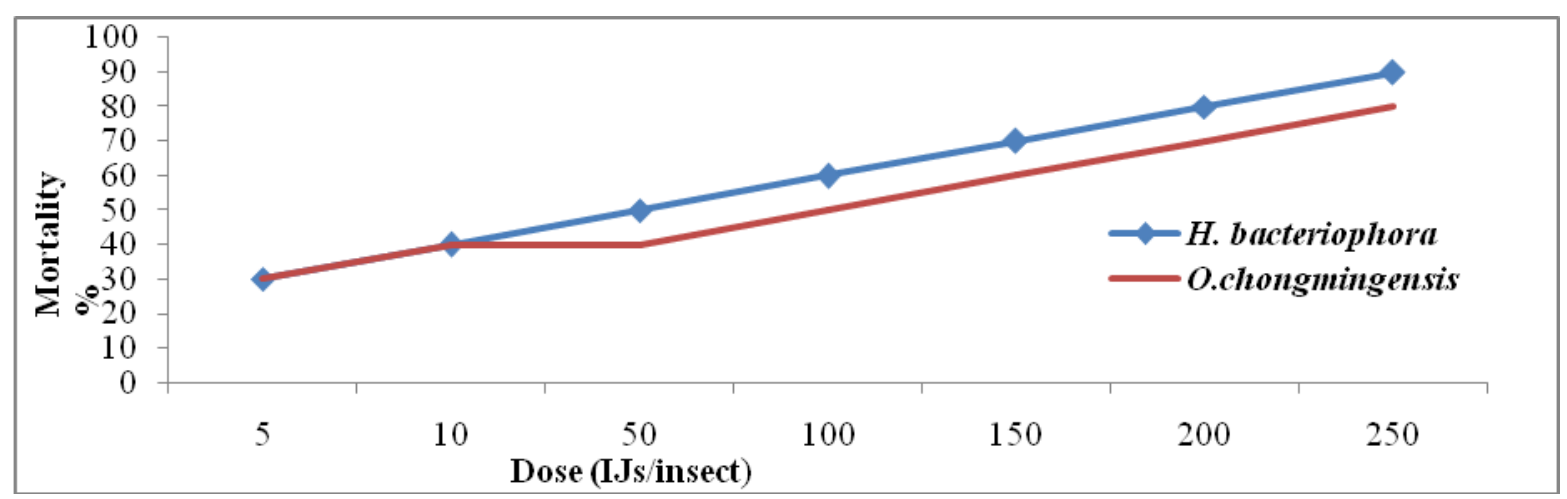

Figure.3 Per cent mortality of $H$. theivora induced by $H$. bacteriophora and $O$. chongmingensis at different concentrations of EPNs at 96h exposure period

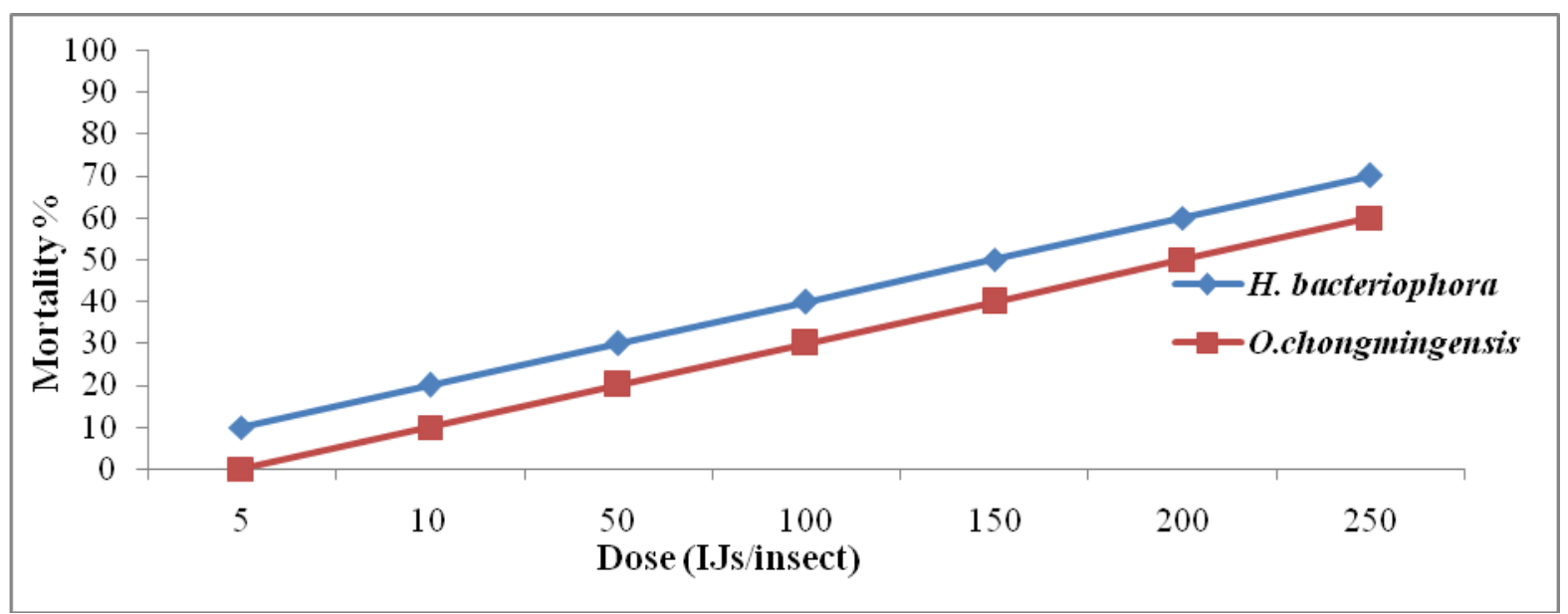

Figure.4 Per cent mortality of A. bipunctata larvae induced by $H$. bacteriophora and $O$. chongmingensis at different concentrations of EPNs at $48 \mathrm{~h}$ of exposure period

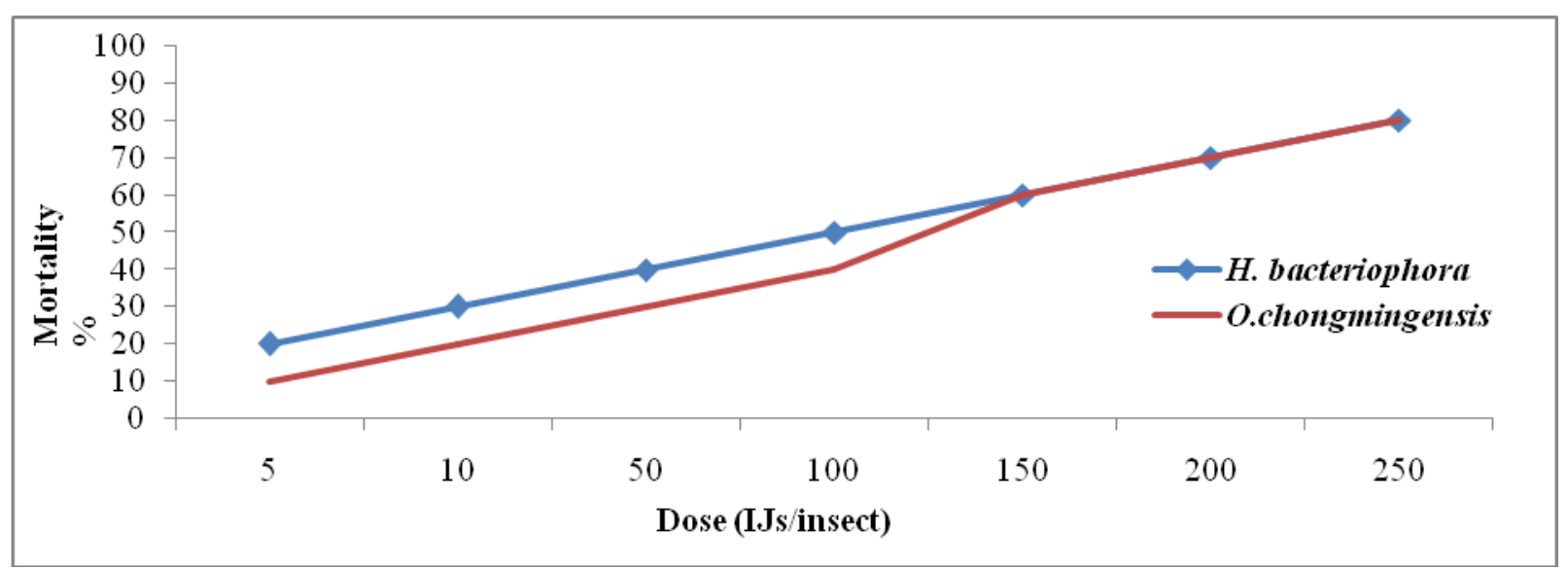

Figure.5 Per cent mortality of A. bipunctata larvae induced by $H$. bacteriophora and $O$. chongmingensis at different concentrations of EPNs at 72h exposure period 


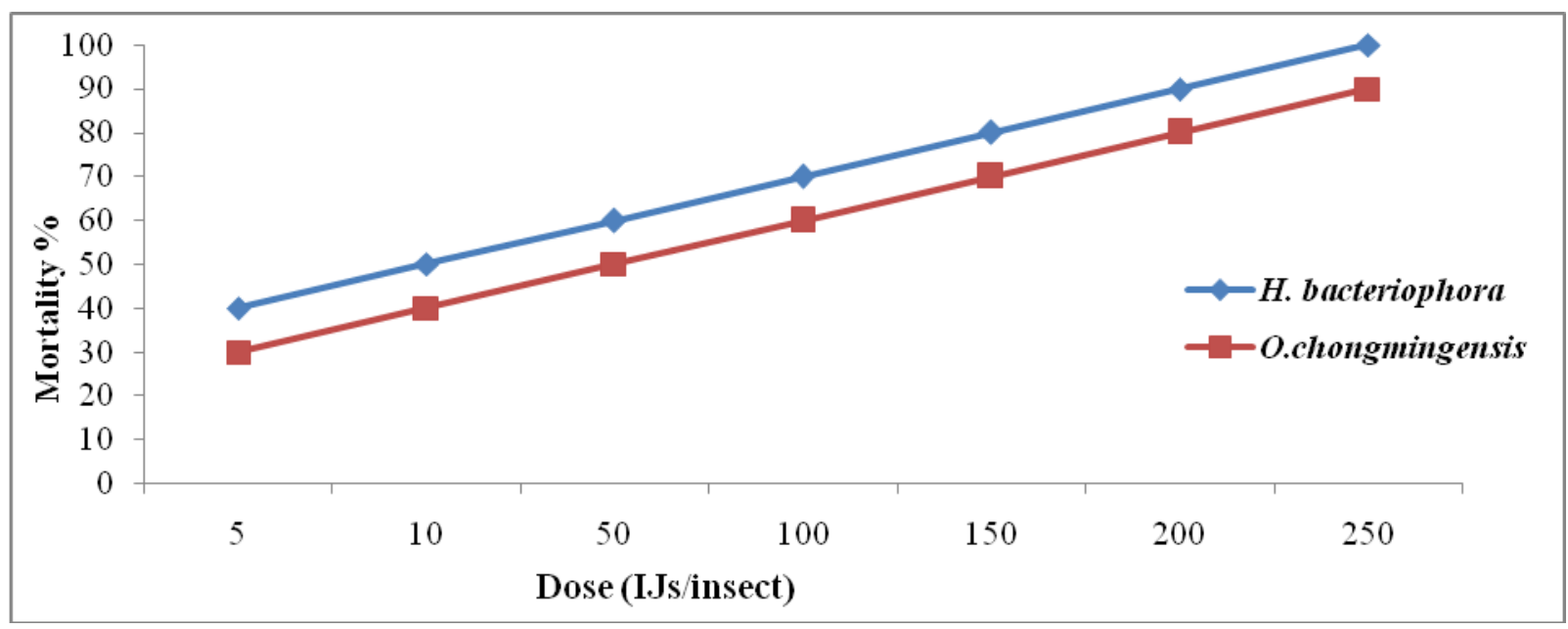

Figure.6 Per cent mortality of $A$. bipunctata induced by $H$. bacteriophora and $O$. chongmingensis larvae at different concentrations of EPNs at 96h exposure period

Lower $\mathrm{LC}_{50}$ values of $H$. indica $(200,34$ and31 IJs/larva) compared to those of Steinernema sp. (275IJs/larva), S. bicornutum (64 IJs/larva) and S.carpocapsae (34 IJs/larva) against Chilopartellu (PDBC, 2000), A. ipsilon (Hussaini et al., 2002) and P. xylostella (Hussaini, 2003), respectively was also recorded. Shinde and Singh (2000) tested eight entomopathogenic nematode species/strains against the final instar larvae of $P$. xylostella. They found that all nematodes species were pathogenic. However, $H$. bacteriophora was the most pathogenic amongst the tested nematodes on the basis of $\mathrm{LC}_{50}$ and $\mathrm{LT}_{50}$.

Due to the associated bacteria, Photorhabdus luminescens and Serratia nematodiphila also reacted differently when in contact with insect hosts (Zhang et al., 2009). Moreover, $H$. bacteriophora is a cruiser forager that actively looks for its prey (Ciche, 2007).

EPNs demonstrated great variation in infectivity in different hosts, and none of the species/strains of EPNs may infect all the tested insect species or some species or strains may be highly host specific (Gaugler et al., 1989; Georgisand Manweiler 1994).
Such variation in the insect mortality by the two nematode species may be attributed, to the host preference by nematodes or host recognition and penetration or nematode's compatibility/virulence with its host, and to the vulnerability of insect pests (stages as well as among the species, the behavioral, morphological and physiological defense strategies of insects (Bedding et al., 1983;Fuxa et al., 1988; Glazer and Navon, 1990;Glazer, et al., 1992; Berry et al., 1997;Glazer and Lewis, 2000; Shapiro-Ilan and Cottrell, 2005).

Moreover, the faster invasion rate was recorded with smaller insects for all nematodes strains. Thus the $\mathrm{LC}_{50}$ and $\mathrm{LT}_{50}$ increase in proportion to the size of insect (Bedding et al., 1983). The time taken for mortality and percent mortality is also greatly influenced by temperature. This was evident from the delayed mortality of $G$. melonella by Steiner nemathermophilum at 10 and $20^{\circ} \mathrm{C}$ whereas mortality was faster at $25-$ $35^{\circ} \mathrm{C}$ (Ganguly and Singh, 2001). Therefore, laboratory screening of EPNs for infectivity is an important component for developing a biological control programme for a particular pest (Ricci et al., 1996). 


\section{References}

Adams, B.J. and Nguyen, K.B. (2002). Taxonomy and systematics. In: Entomopathogenic nematology, Gaugler, A. (ed.) CABI Publishing, Wallingford: UK, pp. 1-33.

Anonymous. (1994). Pest of tea in North East India and Their Control. Memorandum No. 27, Tea Research Association, Tocklai Experimental Station, Jorhat, pp. 231.

Anonymous. (2010). Special bulletin on Tea mosquito bug Helopeltis theivora Waterhouse. Tea Research Association. Plant Protection Division. Tocklai Exp. Stn. Jorhat, Assam. pp.1-10.

Anonymous. (2018). Assam the land of red rivers and blue hill. Indian Brand Equity Foundation. pp. 43-53.

Batista, E.S.P., Auad, A.M., Resende, T.T. and Monteiro, C.M.O. (2011). Screening of entomopathogenic nematodes to control Mahanarvafimbriolata (Hemiptera: Cercopidae). Revista Colombiana de Entomología37: 198-202.

Bedding, R.A., Molyneux A.S. and Akhurst, R.J. (1983). Heterorhabditis spp., Neoaplectanaspp., and Steinernemakraussei: interspecific and intraspecific differences in infectivity for insects. Experimental Parasitology. 55: 249-257.

Berry, R.E., Liu, J. and Groth, E. (1997). Efficacy and persistence of Heterorhabditis marelatus (Rhabditida: Heterorhabditidae) against root weevils (Coleoptera: Curculionidae) in strawberry. Environmental Entomology. 26:465-470.

Borthakur, M., Borthakur, M.C., Kakoty, N.N. and Das, S.C. (1992). Progress in bio-control of tea pests. In: Proceedings of Annual meet of $31^{\text {st }}$ Tocklai Conference, TRA, Tocklai
Experimental Station, Jorhat.

Chen, Z.M. and Chen, X.F. (1989). An analysis of world tea fauna. Journal of Tea Science.9: 73-88.

Ciche, T. (2007). The biology and genome of Heterorhabditis bacteriophora. WormBook. 20:1-9.

Das, G.M.(1965). Pests of tea in North East India and their control. Memorandom No. 27, Tocklai Experimental Station, Tea Research Association, Jorhat, Assam, India. pp. 169-173

Fuxa, J.R., Richter, A.R., Agudelo-Silva, F. (1988). Effect of host age and nematode strain on suceptibility of Spodoptera frugiperda to Steine rnemafeltiae. Journal of Nematology. 20: 91-95.

Ganguly, S and Singh, L.K. (2001). Optimum thermal requirements for infectivity and development of an indigenous entomopathogenic nematode, Steiner nemathermophilum. Indian Journal of Nematology. 31:148-152.

Georgia, R. and Manweiler, S.A. (1994). Thermal adaptation of entomopathogenic nematodes: niche breadth for infection, establishment and reproduction. Journal of Thermal Biology. 19: 245-25.

Glazer, I and Lewis, E.E. (2000). Bioassays for entomopathogenic nematodes. In: Navon A, Ascher KRS, editors. Bioassays of entomopathogenic microbes and nematodes. Wallingford, UK: CABI Publishing; pp. 229-247.

Glazer, I and Navon, A. (1990). Activity and persistence of entomoparasitic nematodes tested against Heliothis armigera Lepidoptera Noctuidae. Journal of Economics Entomology. 83(5):1795-1800.

Glazer, I and Navon, A. (1990). Activity and persistence of entomoparasitic nematodes tested against Heliothis armigera Lepidoptera Noctuidae. Journal of Economics Entomology. 
83(5):1795-1800.

Glazer, I., Klein, M., Navon, A and Nakache, Y. (1992). Comparison of efficacy of entomopathogenic nematodes combined with antidesiccants applied by canopy sprays against three cotton pests (Lepidoptera: Noctuidae). Journal of Economic Entomology. 85: 1636-1641.

Gupta, M., Desai, P. and Pawar, A.O. (1987). The feasibilities of using DD-136 strain of Neoplectanacarpocapsae Weiser for the control of insect pests. Plant Protection Bulletin. 39:16-19.

Gururaj Katti., Padmakumari, A.P. and Prasad J.S. (2003). An entomopathogenic nematode infecting rice yellow stem borer, Scirpophagaincertulas (Walker). Indian Journal of Plant Protection. 31: 80-83.

Hazarika, L.K., Bhuyan, M. and Hazarik, N.B. (2009). Insect pests of tea and their management. Annual Review of Entomology. 54: 267-284.

Hewlett P.S. and Plackett R.L. (1979). Interpretation of quantal responses in Biologes London, Edward Arnd.

Hussaini, S.S. (2003). Progress of Research work on entomopathogenic nematodes in India. In: Current Status of Research on Entomopathogenic Nematodes in India (Hussaini, S.S., Rabindra, R.J. and Nagesh, M. eds. 2003) PDBC, publication, Bangalore, India, 27-69.

Hussaini, S.S., Singh, S.P. and Nagesh, M. (2002). In vitro and field evaluation of some indigenous isolates of Steinernema and Heterorhabditisindica against shoot and fruit borer, Leucinodesorbonalis. Indian Journal of Nematology. 32(1): 63-65.

Kaya, H.K. and Gaugler, R. (1993). Entomopathogenic nematodes.Annual Review of Entomology 38: 181-206.

Kondo, E. and Ishibashi, N. (1986). Infectivity and propagation of entomogenous nematodes,
Steinernemaspp. on the common cutworm, Spodopteralitura (Lepidoptera: Noctuidae). Applied Entomology and Zoology. 21: 95-108.

Leite, L.G., Tavares, F.M., Bussóla, R.A., Amorim, D.S., Ambrós, C.M., Harakava, R. (2007). Virulence of entomopathogenic nematodes (Nemata: Rhabditida) against larva of the fungus gnat Bradysia mabiusi (Lane, 1959) and persistence of Heterorhabditis indica Poinar et al., 1992 on organic substrates. Arquivos do Instituto Biológico, 74:337-342.

Mohandas, C. and Rajamma P. (2005). Rhabditis (Oscheius) sp.- A new entomopathogenic nematode. Pp. 168174. In: Biotechnological management of nematode pests and scope of entomopathogenic nematodes (Sithanantham S., Vasantha Raj, David B. and Selvaraj P., eds). Sun Agro Biotech Research Center, Chennai, India.

Mohandas, C., Mathews, S., Firoza, A.J. and Rajamma P. (2005). Bacteria associated with Rhabditis (Oscheius) spp. (Rhabditidae: Nematoda) for the biocontrol of insect pests. National Seminar on Achievements and Opportunities in Post-harvest Management and Value Addition in Root and Tuber Crops. Central Tuber Crops Research Station, Kayankulam, Kerala, India, pp. 79-80 (abstract).

Negrisoli, C.R.C.B., Nergisoli, A.S., Botton, M., Garcia, M.S. and Bernardi, D. (2013). Evaluation of efficacy of 18 strains of entomopathogenic nematodes (Rhabditida) against Planococcuscitri (Risso, 1813) (Hemiptera: Pseudococcidae) under laboratory conditions. Experimental Parasitology. 134: 295-298.

Padmakumari, A. P., Kstti, G., Sankar, M. and Prasad, J.S. (2005). Efficacy of 
entomopathogenic nematodes on yellow stem borer, Sciropophaga incertulas. In: Biotechnological Management of Nematodes and Scope of entomopathogenic Nematodes (Sithanantham, S., Vasantharaj David, B. and Selvaraj, P., eds.). Directorate of Biological Control, Bangalore, India, pp. 172-174,

Padmakumari, A.P., Prasad, J.S., Gururaj, K. and Sankar, M. (2007). Rhabditis sp. (Oscheiussp.), a biocontrol agent against rice yellow stem borer, Scirpophaga incertulas. Indian Journal of Plant Protection. 35:255-258

Prasad, J.S., Katti, G., Padmakumari, A.P. and Pasalu, I.C. (2003). Exploitation of indigenous entomopathogenic nematodes against insect pests of rice. pp. 121-126. In: Current status of research on entomopathogenic nematodes in India (Hussaini S.S., Rabindra R.J. and Nagesh M., eds). Project Directorate of Biological Control, Bangalore, India.

Rajkumar, M., Parihar, A. and Siddiqui, A.U. (2003). Effect of entomopathogenic nematodes, Heterorhabditis sp. against Spodopteralitura. Annals of Plant Protection Sciences. 11(2): 369-410.

Ratansinghe, G and Hauge, N.G.M. (1995). The susceptibility of diamond back moth Plutellaxylostella (Lepidoptera: Yponomeutidae) to entomopathogenic nematodes. Afro-Asian journal of nematology. 5: 20-23.

Ricci, M., Glazer, I., Campbell, J. F. and Gaugler, R. (1995). Comparison of bioassays to measure evidence of different entomopathogenic nematodes. Biocontrol Science and Technology. 6: $235-245$.

Ricci, M., Glazer, I., Campbell, J. F. and Gaugler, R. (1995). Comparison of bioassays to measure evidence of different entomopathogenic nematodes.
Biocontrol Science and Technology. 6: $235-245$.

Saravanapriya, B and Subramanian, S. 2005. Effect of ph survival, infectivity and reproductively of entomopathogenic nematodes. Current nematology. 16(1/2):85-87.

Shapiro-Ilan, D.I. and Cottrell, T.E. (2005). Susceptibility of lady beetles (Coleoptera: Coccinellidae) to entomopathogenic nematodes. Journal of Invertebrate Pathology. 89: 150-156.

Shinde, S. and Singh, S.P. (2000). Susceptibility of diamondback moth, Plutella xylostella $(\mathrm{L}) \quad$ to entomopathogenic nematodes. Indian Journal of Experimental Biology.38: 956-959.

Stock, S.P., Griffin, C.T. and Burnell, A.M. (2002). Morphological characterization of three isolates of Heterorhabditis Poinar, 1976 from the Irish group (Nematoda:

Rhabditida: Heterorhabditidae) and additional evidence supporting their recognition as a distinct species. H. downesi $n$. sp. Systematic Parasitology. 51 (2): 95-106.

Sundararaju, D. and Sundara Babu, P.C. (1999). Helopeltis spp. (Heteroptera: Miridae) and their management in plantation and horticultural crops of India. Journal of plant Crops. 27:15574.

Torres-Barragan,. A., Suazo, A., Buhler, W.G. and Cardoza, Y.J. (2011). Studies on the entomopathogenicity and bacterial associates of the nematode Oscheius carolinensis. Biological Control 59: 123-129.

Van Niekerk, S., (2012). The Use of Entomopathogenic Nematodes to Control Citrus Mealybug, Planococcuscitri (Hemiptera: Pseudococcidae) on Citrus in South Africa. MSc thesis, Department Conservation Ecology and Entomology, 
Stellenbosch University.

Vyas, R.V. and Yadav, D.N. (1992). Infectivity of entomopathogenic nematodes to the two soil dwelling lepidopterans. Annals of Biology. 8:5963.

Watt, G. and Mann, H.H. (1903).The pests and blights of the tea plant.2nd ed. Calcutta, India, 368-371.

White, G.F. (1927). A method for obtaining infective nematode larvae from cultures. Science (Washington) 6(1709): 302303.

Wilson, K. C. and Clifford, M.N. (1992). "Tea: Cultivation to Consumption," Chapman and Hall, London, p. 792.

Woodring, J.L. and Kaya, H.K. (1988). Steinernematid and heterorhabditid nematodes: A handbook of biology and techniques. Southern Cooperative Series Bulletin 331. Fayetteville, AR: Arkansas Agricultural Experiment Station.

Zaki, M.J. (2000). Biomanagement of root knot nematodes problem of vegetables, p: 131. DFID, UK, Research Project Report. Department of Botany, University of Karachi, Pakistan.

Zhang, C., Liu, J., Xu, M., Sun, J., Yang, S., An, X., Gao, G., Lin, M., Lai., Lai, R., He, Z. and Wu, Y. (2008). Heterorhabditidoides chongmingensis gen. nov., sp. Nov. (Rhabditida:
Rhabditidae), a novel number of the entomopathogenic nematodes. Journal of Invertebrate Pathology 98(2): 153168.

Zhang, K.Y., Liu, X.H., Tan, J., Wang, Y., Qiao, L., Yedid, G., Dai, C.S., Qiu, R.L., Yan, X.W., Tan, H.W., Su, Z.Y., Lai, R. and Gao, G.F. (2012). Heterorhabditidoides rugaoensisn. sp. (Rhabditida: Rhabditidae), a novel highly pathogenic entomopathogenic nematode member of Rhabditidae. Journal of Nematology, 44: 348-360

Zhang, C.X., Yang, S.Y., Xu, M.X., Sun, J., Liu, H., Liu, J.R., Liu, H., Kan, F., Sun, J., Lai, R. and Zhang, K.Y. (2009). A novel species of Serratia, family Enterobacteriaceae: Serratia nematodiphila sp. nov., symbiotically associated with entomopathogenic nematode Heterorhabditidoidesc hongmingensis (Rhabditida: Rhabditidae). International Journal of Systematic and Evolutionary Microbiology. 59:1603-1608.

Zhang, D.X., Yan, L.N., Ji, Y.J., Hewitt, G.M. and Huang, Z.S. (2009). Unexpected relationships of substructured populations in Chinese Locusta migratoria. BMC Evolutionary Biology. 9(1): 144-155.

\section{How to cite this article:}

Bharath Amuri and Gitanjali Devi. 2020. Bio efficacy of Heterorhabditis bacteriophora and Oscheius chongmingensis against Helopeltis theivora and Andraca bipunctata. Int.J.Curr.Microbiol.App.Sci. 9(04): 2460-2473. doi: https://doi.org/10.20546/ijcmas.2020.904.295 